\title{
Effect of Some Halogenated Hydrocarbons on the Flame Speed of Methane
}

\author{
Carl Halpern \\ Institute for Applied Technology, National Bureau of Standards, Washington, D.C.
}

(November 17, 1965)

\begin{abstract}
The effects of five halogenated hydrocarbons on the flame speed of methane have been studied. Bromides are more effective in reducing flame speeds than are chlorides and the reduction in flame speed is proportional to the amount of inhibitor added.
\end{abstract}

Key Words: Flame speed, combustion, inhibitor, halogenated hydrocarbon, bromide, chloride.

\section{Introduction}

Halogenated hydrocarbons have long been used to extinguish unwanted fires and a method of ranking the effectiveness of these compounds was wanted. In a previous paper [1], ${ }^{1}$ the effect of a single inhibitor, methyl bromide $\left(\mathrm{CH}_{3} \mathrm{Br}\right)$, on the flame speed of methane was studied. It was shown that the flame speed was very sensitive to the presence of methyl bromide and that the maximum flame speed for given experimental conditions decreased proportionally as the concentration of inhibitor increased. It appeared that the decrease in maximum flame speed could be used as a measure of the effectiveness of flame inhibitors.

In the present work, the effects of five additional inhibitors were studied. The inhibitors were bromotrifluoromethane, $\mathrm{CF}_{3} \mathrm{Br}$ : dibromodifluoromethane, $\mathrm{CF}_{2} \mathrm{Br}_{2}$ : methyl chloride, $\mathrm{CH}_{3} \mathrm{Cl}$ : chlorotrifluoromethane, $\mathrm{CF}_{3} \mathrm{Cl}$; and dichlorofluoromethane, $\mathrm{CHFCl}_{2}$.

\section{Apparatus and Procedure}

The apparatus and method of measuring flame speeds have been described in previous publications $[1,2]$. Briefly, the apparatus consists of drying and metering sections for air and fuel and a nozzle, the exit of which is the port of the burner. Means are

'Figures in brackets indicate the literature references at the end of this paper. provided to measure and control the temperature of the combustible mixture. Flame speeds are determined by a total area method which is based on the measurement of the area of the schlieren image of the inner flame cone and on the measurement of the rates of flow of fuel and air.

Mixtures of inhibitor and dry air were prepared in a large steel tank and were metered by observing the pressure drop across a calibrated sharp-edged orifice. Some error is introduced since the orifice was calibrated for air, but in view of the small quantities of inhibitor used (maximum quantity was 0.5 percent, by volume, of the air), it was felt that the error would be tolerable.

Mixtures in air of $0.1,0.2,0.3,0.4$, and 0.5 percent, by volume, of each inhibitor were prepared. The variation of flame speed with mixture ratio ${ }^{2}$ was determined for each mixture, the gas velocity at the nozzle remaining constant. Mixture ratio was varied from 0.054 to 0.072 . (A stoichiometric mixture of methane and air is equivalent to mixture ratio 0.0583 .)

Flame speeds of the 0.1 percent mixture of each inhibitor were determined at gas velocities measured at the port of the nozzle of $3,4,5$ and $6 \mathrm{ft} / \mathrm{s}$. This procedure was adopted to determine the variation of flame speed with gas velocity over an extended range. For all other mixtures, flame speeds were determined only at gas velocities of 4 and $5 \mathrm{ft} / \mathrm{s}$. 2Mixture ratio is here defined as the weight of methane divided by the weight of air, or
in the case of an inhibited mixture, as the weight of methane divided by the weight of air plus added inhibitor. 
Variation of flame speed with initial temperature was determined for mixtures containing each inhibitor. Mixture ratio was $0.060 ; 0.2$ percent of inhibitor was added to the air; and the gas velocity was $4 \mathrm{ft} / \mathrm{s}$. The range of temperatures in these determinations was from 75 to $100{ }^{\circ} \mathrm{F}$. Flame speed increased as the temperature increased and the change of flame speed with temperature was found to be linear. The results, together with values for methane and methane plus methyl bromide taken from previous work, are listed in table 1. These values were used to correct all flame speeds to $75^{\circ} \mathrm{F}$.
TABLE 1. Variation of flame speed with initial mixture temperature

\begin{tabular}{l|c}
\hline \multicolumn{1}{c|}{ Inhibitor } & Feet per sec per ${ }^{\circ} \mathrm{F}$ \\
\hline & 0.00391 \\
Methane $^{\text {a }}$ & .00328 \\
Methyl bromide $^{\mathrm{b}}$ & .00329 \\
Bromotrifluoromethane & .00200 \\
Dibromdifluoromethane & .00322 \\
Methyl chloride & .00199 \\
Dichlorofluoromethane & .00504 \\
Chlorotrifluoromethane & \\
\hline \multicolumn{2}{|c}{} \\
${ }^{\text {a } V a l u e ~ f o r ~ m e t h a n e ~ i s ~ t a k e n ~ f r o m ~[2] . ~}$ \\
b Value for methyl bromide is taken from [7].
\end{tabular}

TABLE 2. Maximum flame speeds

\begin{tabular}{|c|c|c|c|c|c|}
\hline Inhibitor & Flame speed & $\begin{array}{l}\text { Inhibitor } \\
\text { added }\end{array}$ & $\frac{\text { wt. } \mathrm{CH}_{4}}{\text { wt. air }+ \text { inhib. }}$ & $\frac{\text { Flame speed }}{\text { Flame speed, } \mathrm{CH}_{4}} \times 100$ & $\begin{array}{c}\text { Gas } \\
\text { velocity }\end{array}$ \\
\hline $\mathrm{CF}_{3} \mathrm{Br}$ & $\begin{array}{c}f t / s \\
1.208 \\
1.196 \\
1.171 \\
1.166 \\
1.068 \\
1.061 \\
1.012 \\
1.016 \\
0.932 \\
{ }^{a} .950 \\
{ }^{\circ} .857 \\
{ }^{c} .856\end{array}$ & $\begin{array}{r}\% \\
0.1 \\
.1 \\
.1 \\
.1 \\
.2 \\
.2 \\
.3 \\
.3 \\
.4 \\
.4 \\
.5 \\
.5\end{array}$ & $\begin{array}{r}0.0602 \\
.0601 \\
.0600 \\
.0599 \\
.0600 \\
.0620 \\
.0582 \\
.0620 \\
.0580 \\
.0620 \\
.0600 \\
.0640\end{array}$ & $\begin{array}{r}101.0 \\
100.0 \\
97.9 \\
97.5 \\
89.3 \\
88.8 \\
84.6 \\
85.0 \\
78.0 \\
79.4 \\
71.6 \\
71.6\end{array}$ & $\begin{array}{c}f t / s \\
3 \\
4 \\
5 \\
6 \\
4 \\
5 \\
4 \\
5 \\
4 \\
5 \\
4 \\
5\end{array}$ \\
\hline $\mathrm{CF}_{2} \mathrm{Br}_{2}$ & $\begin{array}{r}1.151 \\
1.124 \\
1.113 \\
\mathrm{~d} .107 \\
0.970 \\
.977 \\
\mathrm{e} .881 \\
\mathrm{i} .844 \\
\mathrm{~g} .775 \\
\mathrm{~h} .638 \\
.578 \\
. .500\end{array}$ & $\begin{array}{l}.1 \\
.1 \\
.1 \\
.1 \\
.2 \\
.2 \\
.3 \\
.3 \\
.4 \\
.4 \\
.5 \\
.5\end{array}$ & $\begin{array}{l}.0580 \\
.0581 \\
.0621 \\
.0601 \\
.0581 \\
.0617 \\
.0600 \\
.0641 \\
.0620 \\
.0681 \\
.0661 \\
.0720\end{array}$ & $\begin{array}{l}96.2 \\
94.0 \\
93.0 \\
92.6 \\
81.1 \\
81.7 \\
73.6 \\
70.6 \\
64.8 \\
53.4 \\
48.3 \\
41.8\end{array}$ & $\begin{array}{l}3 \\
4 \\
5 \\
6 \\
4 \\
5 \\
4 \\
5 \\
4 \\
5 \\
4 \\
5\end{array}$ \\
\hline $\mathrm{CH}_{3} \mathrm{Cl}$ & $\begin{array}{l}1.242 \\
1.236 \\
1.224 \\
1.231 \\
1.208 \\
1.197\end{array}$ & $\begin{array}{l}.1 \\
.1 \\
.3 \\
.3 \\
.5 \\
.5\end{array}$ & $\begin{array}{l}.0600 \\
.0601 \\
.0601 \\
.0581 \\
.0601 \\
.0581\end{array}$ & $\begin{array}{l}103.9 \\
103.4 \\
102.4 \\
103.0 \\
101.0 \\
100.1\end{array}$ & $\begin{array}{l}4 \\
5 \\
4 \\
5 \\
4 \\
5\end{array}$ \\
\hline $\mathrm{CF}_{3} \mathrm{Cl}$ & $\begin{array}{l}1.320 \\
1.274 \\
1.208 \\
1.238 \\
1.271 \\
1.195 \\
1.248 \\
1.143 \\
1.122 \\
1.127 \\
1.139 \\
1.105\end{array}$ & $\begin{array}{l}.1 \\
.1 \\
.1 \\
.1 \\
.2 \\
.2 \\
.3 \\
.3 \\
.4 \\
.4 \\
.5 \\
.5\end{array}$ & $\begin{array}{l}.0603 \\
.0621 \\
.0621 \\
.0620 \\
.0581 \\
.0600 \\
.0581 \\
.0600 \\
.0581 \\
.0600 \\
.0601 \\
.0579\end{array}$ & $\begin{array}{r}110.4 \\
106.5 \\
101.0 \\
103.5 \\
106.3 \\
100.0 \\
104.4 \\
95.6 \\
93.8 \\
94.3 \\
95.3 \\
92.4\end{array}$ & $\begin{array}{l}3 \\
4 \\
5 \\
6 \\
4 \\
5 \\
4 \\
5 \\
4 \\
5 \\
4 \\
5\end{array}$ \\
\hline $\mathrm{CHCl}_{2} \mathrm{~F}$ & $\begin{array}{l}1.321 \\
1.296 \\
1.257 \\
1.233 \\
1.302 \\
1.221 \\
1.151 \\
1.141 \\
1.136 \\
1.139 \\
1.113 \\
1.121\end{array}$ & $\begin{array}{l}.1 \\
.1 \\
.1 \\
.1 \\
.2 \\
.2 \\
.3 \\
.3 \\
.4 \\
.4 \\
.5 \\
.5\end{array}$ & $\begin{array}{l}.0579 \\
.0600 \\
.0578 \\
.0600 \\
.0580 \\
.0600 \\
.0600 \\
.0580 \\
.0601 \\
.0600 \\
.0599 \\
.0600\end{array}$ & $\begin{array}{r}110.5 \\
108.3 \\
105.1 \\
103.1 \\
108.8 \\
102.1 \\
96.3 \\
95.4 \\
95.2 \\
95.3 \\
93.1 \\
93.8\end{array}$ & $\begin{array}{l}3 \\
4 \\
5 \\
6 \\
4 \\
5 \\
4 \\
5 \\
4 \\
5 \\
4 \\
5\end{array}$ \\
\hline 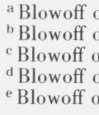 & $\begin{array}{l}\text { Irred at } 0.060 \text {. } \\
\text { irred at } 0.058 \text {. } \\
\text { irred at } 0.062 \text {. } \\
\text { irred at } 0.058 \text {. } \\
\text { irred at } 0.058 \text {. }\end{array}$ & & $\begin{array}{l}\text { lowoff occurred } \\
\text { lowoff occurred } \\
\text { llowoff occurred } \\
\text { lowoff occurred } \\
\text { lowoff occurred }\end{array}$ & $\begin{array}{l}0.062 \\
0.060 \\
0.066 \\
0.064 \\
0.070\end{array}$ & \\
\hline
\end{tabular}




\section{Results}

The outer mantle of flames to which bromine inhibitors were added was colored brown presumably by the formation of free bromine and the odor of bromine was noticeable. Hydrogen bromide is also thought to be present in the combustion products. Flames containing chlorine inhibitors were brighter than methane-air flames and the acid odor of hydrogen chloride was noticeable.

Water condensed on the surface of the nozzle during some experiments and this condensate was found to react acid; copper was also detected in the condensate. In other experiments, solid products of corrosion, most likely halides of copper and zinc, were formed around the port of the nozzle. In some instances, this deposit developed in quantities sufficient to interfere with the flow of gas and cause distorted flames. However, these deposits were soft and easily removed.

At the end of the experiments, the upper surface of the nozzle was found to be eaten away to a depth of $1 / 16$ in. beginning about $0.02 \mathrm{in}$. from the lip and extending outward about $1 / 4$ in., thus leaving a thin rim of untouched metal surrounding the port of the nozzle. This eroded area occupied a position which could not affect the flow of gas.

Maximum flame speed observed for each experimental condition is listed in table 2.

\subsection{Bromotrifluoromethane, $\mathrm{CF}_{3} \mathrm{Br}$}

The addition of $\mathrm{CF}_{3} \mathrm{Br}$ generally resulted in a decrease in the flame speed of methane-air mixtures. However, at a few experimental conditions, an increase in flame speed was observed. At a gas velocity of $3 \mathrm{ft} / \mathrm{s}$ and with 0.1 percent of $\mathrm{CF}_{3} \mathrm{Br}$ added to the combustion air, the maximum flame speed, which occurred at mixture ratio 0.062 , was found to be greater than that of methane-air $-1.208 \mathrm{ft} / \mathrm{s}$ as compared to 1.196 $\mathrm{ft} / \mathrm{s}$. At conditions leaner in fuel than mixture ratio 0.062 , the flame speeds were also greater than those of methane-air. At conditions richer in fuel than mixture ratio 0.062 , flame speeds were lower than those of methane-air. At a gas velocity of $4 \mathrm{ft} / \mathrm{s}$ and with 0.1 percent $\mathrm{CF}_{3} \mathrm{Br}$ present in the combustion air, maximum flame speed was found at mixture ratio 0.060 and was equal to that of methane-air $1.196 \mathrm{ft} / \mathrm{s}$. At conditions leaner in fuel than mixture ratio 0.060 , flame speeds were increased by the presence of $\mathrm{CF}_{3} \mathrm{Br}$, but at conditions richer in fuel than mixture ratio 0.060 , flame speeds were decreased. At gas velocities of 5 and $6 \mathrm{ft} / \mathrm{s}$ and with 0.1 percent $\mathrm{CF}_{3} \mathrm{Br}$ added, flame speeds were always less than those of methane-air. Flame speeds of mixtures containing 0.2 percent of $\mathrm{CF}_{3} \mathrm{Br}$ and more added to the air were always less than those for methane-air.
At a gas velocity of $3 \mathrm{ft} / \mathrm{s}$, the addition of 0.1 percent of $\mathrm{CF}_{2} \mathrm{Br}_{2}$ to the combustion air decreased the flame speed of methanie-air except at two conditions, at mixture ratios of 0.054 and 0.056 , where a slight increase in flame speed was noted. At all other experimental conditions of gas velocity, mixture ratio, and concentration of inhibitor, flame speed was decreased by the addition of $\mathrm{CF}_{2} \mathrm{Br}_{2}$. All maximum flame speeds at given conditions were lower than those of methanair and are listed in table 2. Reduction in flame speed at given mixture ratio and gas velocity was found to be directly proportional to the amount of $\mathrm{CF}_{2} \mathrm{Br}_{2}$ added. The decrease in maximum flame speed for a given addition of $\mathrm{CF}_{2} \mathrm{Br}_{2}$ was also found to be directly proportional to the amount of inhibitor added and was found to be $0.1450 \mathrm{ft} / \mathrm{s}$ for each 0.1 percent addition, in the range of concentrations used in these experiments. Variation of flame speed with mixture ratio is presented in figures 4 and 5 .

Why $\mathrm{CF}_{3} \mathrm{Br}$ should be more effective as an inhibitor than $\mathrm{CH}_{3} \mathrm{Br}$ is not apparent. Fluorine atoms seem to have little or no inhibiting power. If fluorine, as an inhibitor, were comparable to bromine, one would expect $\mathrm{CF}_{3} \mathrm{Br}$ to be much more effective than $\mathrm{CH}_{3} \mathrm{Br}$ which is not the case. If, as has been proposed [4], hydrogen halides are formed in the reaction zone and are the effective inhibitors, then hydrogen fluoride is either not present or is too stable to react with the chain-carrying radicals. The carbon to fluorine bond has a heat of formation of $107 \mathrm{kcal} / \mathrm{mol}$ while the carbon to bromine bond has a heat of formation of 54 $\mathrm{kcal} / \mathrm{mol}$. Likewise, the hydrogen to fluorine bond has a heat of formation much larger than the hydrogen to bromine bond: $147.5 \mathrm{kcal} / \mathrm{mol}$ as compared to 87.3 $\mathrm{kcal} / \mathrm{mol}[3]$. Since fluorine bonds are much stronger, it is less likely that they would rupture in the comparatively low temperature methane-air flames. The possibility exists that the hydrogen atoms of $\mathrm{CH}_{3} \mathrm{Br}$ may act as centers of chain initiation and counterbalance the chain-breaking activities of the bromine atom. But if this process does occur, it must play a very minor role as the maximum flame speeds, produced by inhibition by $\mathrm{CF}_{3} \mathrm{Br}$ and $\mathrm{CH}_{3} \mathrm{Br}$, are very close in magnitude.

$\mathrm{CF}_{3} \mathrm{Br}$ and $\mathrm{CF}_{2} \mathrm{Br}_{2}$, under certain circumstances, actually increase the flame speed of methane. In our previous work with $\mathrm{CH}_{3} \mathrm{Br}$, some instances of increased flame speed were also found and the opinion was expressed that $\mathrm{CH}_{3} \mathrm{Br}$ in an excess of air probably acted as a fuel [1].

$\mathrm{CF}_{3} \mathrm{Br}$ and $\mathrm{CF}_{2} \mathrm{Br}_{2}$ increase flame speeds only when 0.1 percent is added to the combustion air and in lean mixtures, that is, in mixtures which contain an excess of air. The mixture ratio at which maximum flame speed occurs, as compared to methane, is shifted toward the lean side. This exactly parallels the behavior of $\mathrm{CH}_{3} \mathrm{Br}$ and suggests that $\mathrm{CF}_{3} \mathrm{Br}$ and $\mathrm{CF}_{2} \mathrm{Br}_{2}$ may also act as fuels in an excess of air. 


\subsection{Comparison of Bromine Inhibitors}

A comparison of the maximum flame speeds of methane-air mixtures to which the bromine-containing inhibitors $\mathrm{CH}_{3} \mathrm{Br}, \mathrm{CF}_{3} \mathrm{Br}$, and $\mathrm{CF}_{2} \mathrm{Br}_{2}$ were added shows $\mathrm{CF}_{2} \mathrm{Br}_{2}$ to be the most effective in reducing flame speeds. For example, at a gas velocity of 4 $\mathrm{ft} / \mathrm{s}, 0.3$ percent $\mathrm{CH}_{3} \mathrm{Br}$ added to air resulted in a maximum flame speed of $1.029 \mathrm{ft} / \mathrm{s}$ which is 86.0 percent of the maximum flame speed of methane-air. The same concentration of $\mathrm{CF}_{3} \mathrm{Br}$ in the burning mixture yielded a maximum flame speed of $1.012 \mathrm{ft} / \mathrm{s}$ or 84.6 percent of the maximum flame speed of methane-air. The same concentration of $\mathrm{CF}_{2} \mathrm{Br}$. in the burning mixture resulted in a maximum flame speed of $0.881 \mathrm{ft} / \mathrm{s}$ or 73.6 percent of the maximum flame speed of methane-air. Maximum flame speeds of mixtures inhibited by $\mathrm{CF}_{3} \mathrm{Br}$ and $\mathrm{CF}_{2} \mathrm{Br}_{2}$ are listed in table 2 . Maximum flame speeds for mixtures containing $\mathrm{CH}_{3} \mathrm{Br}$ are listed in [1]. The rate of decrease in maximum flame speed with the increase in concentration of inhibitor is also greatest for $\mathrm{CF}_{2} \mathrm{Br}_{2}$. These rates are listed in table 3. The fact that $\mathrm{CF}_{2} \mathrm{Br}_{2}$ contains two bromine atoms to one in both $\mathrm{CH}_{3} \mathrm{Br}$ and $\mathrm{CF}_{3} \mathrm{Br}$ suggests that increasing the number of bromine atoms in the molecule also increases its inhibiting powers.

Flame speeds of methane-air mixtures inhibited by $\mathrm{CF}_{3} \mathrm{Br}$ are lower than those containing the same volume of $\mathrm{CH}_{3} \mathrm{Br}$ except in two cases: at a gas velocity of $3 \mathrm{ft} / \mathrm{s}$ with 0.1 percent inhibitor present and at a gas velocity of $4 \mathrm{ft} / \mathrm{s}$ with 0.1 percent inhibitor present. Flame speeds of mixtures containing $\mathrm{CF}_{3} \mathrm{Br}$ are about 98 percent of the flame speeds of the corresponding mixture containing $\mathrm{CH}_{3} \mathrm{Br}$. The rates of decrease of flame speed with increasing concentration of inhibitor are similar in magnitude and are listed in table 3.

TABLE 3. Variation of maximum flame speeds with added inhibitor

\begin{tabular}{l|c}
\hline \hline Inhibitor & $\begin{array}{c}\text { Decrease in flame speed for } \\
\text { each 0.1\% added inhibitor }\end{array}$ \\
\hline & $f t / s$ \\
$\mathrm{CH}_{3} \mathrm{Br}^{\mathrm{a}}$ & 0.0828 \\
$\mathrm{CF}_{3} \mathrm{Br}$ & .0823 \\
$\mathrm{CF}_{3} \mathrm{Br}_{2}$ & .1450 \\
$\mathrm{CH}_{3} \mathrm{Cl}$ & .00922 \\
$\mathrm{CF}_{3} \mathrm{Cl}$ & .0313 \\
$\mathrm{CHCl}_{2} \mathrm{~F}$ & .0398 \\
\hline
\end{tabular}

a Value for $\mathrm{CH}_{3} \mathrm{Br}$ is taken from [1].

Flame speeds at constant gas velocity and at constant mixture ratio were found to decrease as the amount of $\mathrm{CF}_{3} \mathrm{Br}$ added to the air was increased and the decrease in flame speed was proportional to the amount of $\mathrm{CF}_{3} \mathrm{Br}$ added. Maximum flame speeds were also found to decrease as the amount of $\mathrm{CF}_{3} \mathrm{Br}$ was increased, and this decrease amounted to 0.0823 $\mathrm{ft} / \mathrm{s}$ for each 0.1 percent added, over the range of addition here tested. Rates of decrease of flame speed are listed in table 3 . Figure 1 presents the variation of flame speed with mixture ratio for methane, while in figures 2 and 3 , the effect of addition of $\mathrm{CF}_{3} \mathrm{Br}$ on the variation of flame speed with mixture ratio is presented.

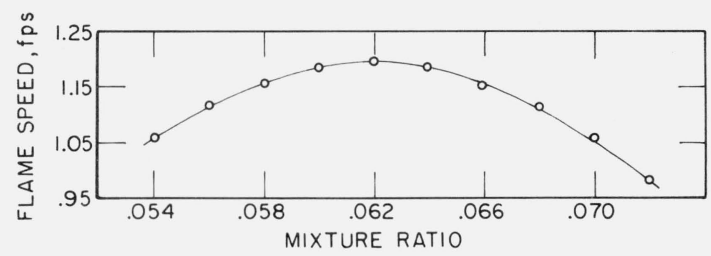

FIGURE 1. Variation of flame speed of methane-air with mixture ratio. Gas velocity $=6 \mathrm{ft} / \mathrm{s}$
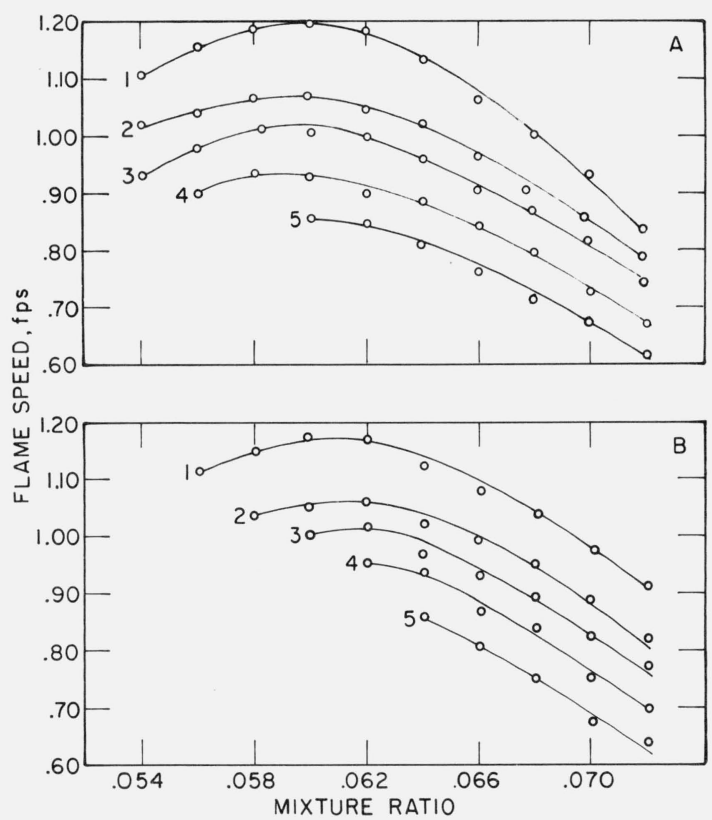

FiguRE 2. Effect of $\mathrm{CF}_{3} \mathrm{Br}$ on the flame speed of methane-air. $\mathrm{CF}_{3} \mathrm{Br}$ added: $1=0.1 \%: 2=0.2 \%: 3=0.3 \%: 4=0.4 \%$ : and $5=0.5 \%$. Gas velocity: $A=4 \mathrm{ft} / \mathrm{s}$ and $B=5 \mathrm{ft} / \mathrm{s}$.

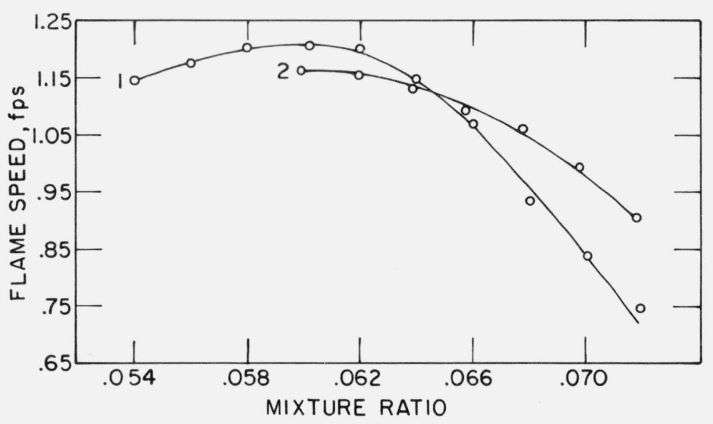

FigurE 3. Effect of $\mathrm{CF}_{3} \mathrm{Br}$ on the flame speed of methane-air. $0.1 \% \mathrm{CF}_{3} \mathrm{Br}$ added. Gas velocity: $\mathrm{l}=3 \mathrm{ft} / \mathrm{s}$ and $2=6 \mathrm{ft} / \mathrm{s}$. 

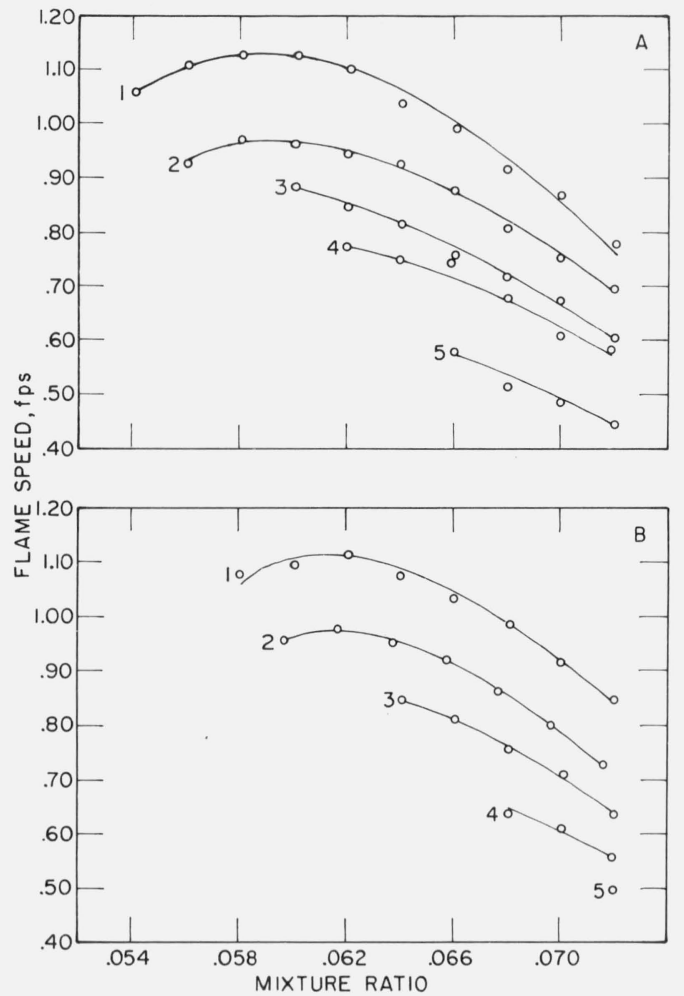

FigURE 4. Effect of $\mathrm{CF}_{2} \mathrm{Br}_{2}$ on the flame speed of methane-air. $\mathrm{CF}_{2 \mathrm{~B}}$ added: $1=0.1 \%: 2=0.2 \%: 3=0.3 \%: 4=0.4 \%:$ and $5=0.5 \%$. Gas velocity: $A=4 \mathrm{ft} / \mathrm{s}$ and $B=5 \mathrm{ft} / \mathrm{s}$.

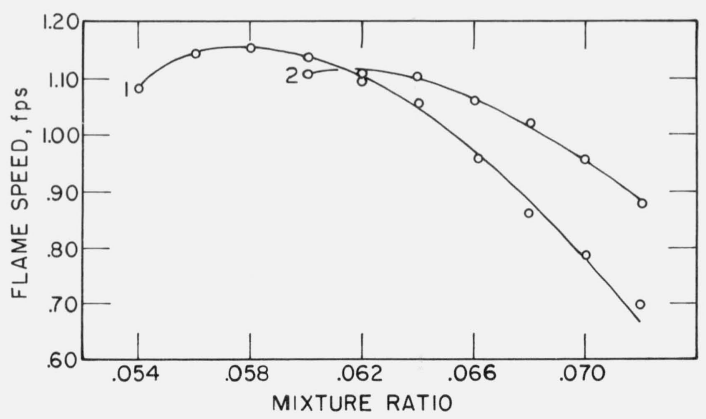

FigurE 5. Effect of $\mathrm{CF}_{2} \mathrm{Br}_{2}$ on the flame speed of methane-air. $0.1 \% \mathrm{CF}_{2} \mathrm{Br}_{2}$ added. Gas velocity: $1=3 \mathrm{ft} / \mathrm{s}$ and $2=6 \mathrm{ft} / \mathrm{s}$.

Cullis, Fish, and Ward have reported on the effect of compounds of bromine on the slow, low-temperature oxidation of methane, among other fuels [5]. They find that these compounds, $\mathrm{HBr}$ and various bromomethanes, exert both a promoting and inhibiting effect on the rate of oxidation. They consider that $\mathrm{HBr}$ is formed from the bromomethanes and is the active agent. From a consideration of activation energies, it is deduced that $\mathrm{HBr}$ reacts easier with $\mathrm{O}_{2}$ than does $\mathrm{CH}_{4}$ and provides another mode of chain initiation. Thus, they account for the promoting action of $\mathrm{HBr}$.
In the later stages of the reaction of $\mathrm{O}_{2}$ and $\mathrm{CH}_{4}$, $\mathrm{HBr}$ reacts with the $\mathrm{OH}$ radical, retarding chain branching and so acts as an inhibitor.

It is questionable whether results obtained from the slow oxidation of $\mathrm{CH}_{4}$ at low temperatures can be applied directly to the fast, high temperature combustion in a flame. However, the view that inhibitors may act as fuels in an excess of air is not incompatible with the view that inhibitors react easier with oxygen than does methane. Whatever the explanation, there is no doubt that low concentrations of bromine compounds can act as promotors in lean mixtures.

\subsection{Inhibitors Containing Chlorine}

Experimental results obtained with inhibitors containing chlorine were not as regular or as consistent as those obtained with bromine compounds. No conclusions could be drawn from the first set of experiments with $\mathrm{CH}_{3} \mathrm{Cl}$ as the results were completely erratic. A second set of experiments was run with additions of $0.1,0.3$, and 0.5 percent, by volume, of $\mathrm{CH}_{3} \mathrm{Cl}$ to the combustion air, at gas velocities of 4 and $5 \mathrm{ft} / \mathrm{s}$. Results from these experiments were more regular and coherent. $\mathrm{CF}_{3} \mathrm{Cl}$ and $\mathrm{CHCl}_{2} \mathrm{~F}$ behaved alike: there was some scatter of the data and some inconsistencies, but a pattern of the effect of these compounds on flame speed could be made out.

Why chlorine compounds should behave erratically is not clear. Deficiencies in experimental techniques may be partly responsible, but the same techniques were used with bromine inhibitors which yielded much more coherent data. HCl which is formed in the flame from chlorine compounds is corrosive to the brass nozzle and copper chloride, which is one of the products of corrosion, is itself an inhibitor [6]. It is possible that deposits of copper chloride around the port of the burner could have affected the flame speed. On occasion, bright blue-green flashes caused by the entrance of copper chloride were observed. But then the flame was extinguished, the nozzle was cleaned and the flame was relit before photographs were taken. Nevertheless, the possibility of metallic halides influencing the flame speed must be borne in mind.

\subsection{Methyl Chloride, $\mathrm{CH}_{3} \mathrm{Cl}$}

Variation of flame speed with mixture ratio was determined at additions of $0.1,0.3$, and 0.5 percent of $\mathrm{CH}_{3} \mathrm{Cl}$ at gas velocities of 4 and $5 \mathrm{ft} / \mathrm{s}$. Results of these experiments are shown in figure 6. Maximum flame speeds for given experimental conditions are listed in table 2.

Methyl chloride did not prove to be an effective inhibitor of the combustion of methane. In fact, at most experimental conditions, it acted as a combustion promoter. Maximum flame speeds of methane-air mixtures containing up to 0.5 percent methyl chloride, added to the air, were larger than those of methaneair. Maximum flame speeds, at a gas velocity of 


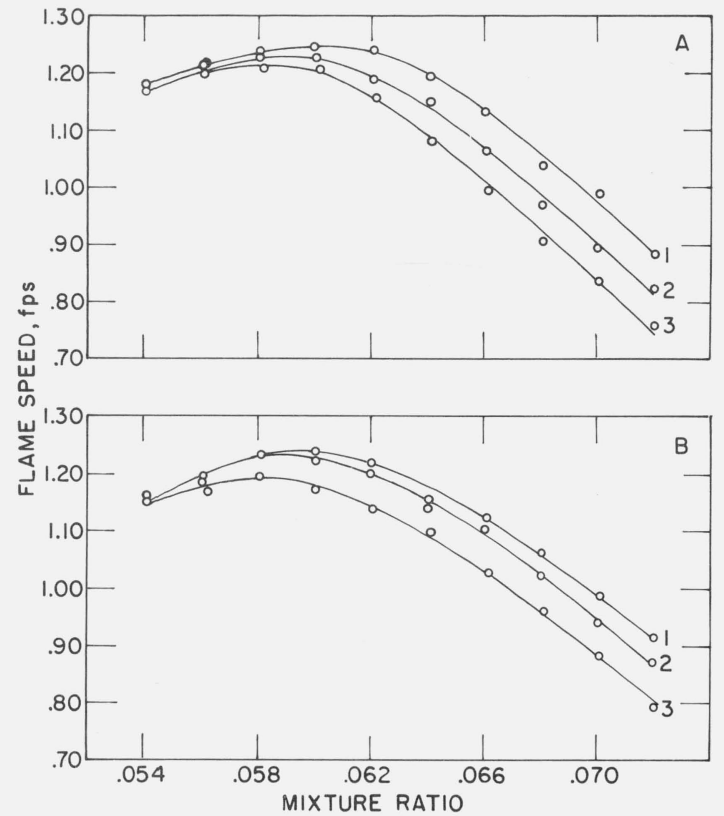

Figure 6. Effect of $\mathrm{CH}_{3} \mathrm{Cl}$ on the flame speed of methane-air. $\mathrm{CH}_{3} \mathrm{Cl}$ added: $\mathrm{I}=0.1 \%: 2=0.3 \%$ : and $3=0.5 \%$. Gas velocity: $A=4 \mathrm{ft} / \mathrm{s}$ and $B=5 \mathrm{ft} / \mathrm{s}$.

$4 \mathrm{ft} / \mathrm{s}$ were $1.242,1.225$, and $1.208 \mathrm{ft} / \mathrm{s}$ for $0.1,0.3$, and 0.5 percent addition, respectively, while the maximum flame speed of methane-air is $1.196 \mathrm{ft} / \mathrm{s}$. Mixtures to which $\mathrm{CH}_{3} \mathrm{Cl}$ was added and which contained less fuel than those which gave the maximum flame speeds always resulted in flame speeds that were larger than the corresponding flame speeds of methane-air. Mixtures to which $\mathrm{CH}_{3} \mathrm{Cl}$ was added gave flame speeds which were smaller than the corresponding flame speed of methane-air only when the mixture contained less fuel than mixture ratio 0.062 .

However, flame speeds of these mixtures did decrease as the amount of $\mathrm{CH}_{3} \mathrm{CI}$ was increased. The decrease in flame speed at a given mixture-ratio was proportional to the amount of $\mathrm{CH}_{3} \mathrm{Cl}$ added. The decrease in maximum flame speeds was also proportional to the amount of $\mathrm{CH}_{3} \mathrm{Cl}$ added and was 0.00922 $\mathrm{ft} / \mathrm{s}$ for each 0.1 percent of $\mathrm{CH}_{3} \mathrm{Cl}$ added.

\subsection{Chlorotrifluoromethane, $\mathrm{CF}_{3} \mathrm{Cl}$}

Maximum flame speeds determined at $4 \mathrm{ft} / \mathrm{s}$ for mixtures containing up to 0.3 percent of $\mathrm{CF}_{3} \mathrm{Cl}$ added to the air, and maximum flame speeds determined at $5 \mathrm{ft} / \mathrm{s}$ for mixtures containing up to 0.2 percent $\mathrm{CF}_{3} \mathrm{Cl}$ added to the air, were larger than the maximum flame speed of methane-air. Mixtures containing more than these amounts of $\mathrm{CF}_{3} \mathrm{Cl}$ resulted in flame speeds which were less than those of methane-air. Thus, $\mathrm{CF}_{3} \mathrm{Cl}$ can act both as a promotor and as an inhibitor of the combustion of methane. In fuel-rich mixtures $\mathrm{CF}_{3} \mathrm{Cl}$ consistently acts as an inhibitor. At mixture ratio 0.072 , flame speeds of all mixtures containing up to 0.5 percent $\mathrm{CF}_{3} \mathrm{Cl}$ were always less than the corresponding flame speed of methane-air. In mixtures containing up to 0.3 percent $\mathrm{CF}_{3} \mathrm{Cl}$ at a gas velocity of $4 \mathrm{ft} / \mathrm{s}$, the flame speed becomes less than that of the corresponding methane-air mixture only at mixture ratio about 0.064 ; at leaner conditions, the flame speed is larger.

Variation of flame speed with mixture ratio is presented in figures 7 and 8 . Maximum flame speeds for given conditions are listed in table 2.

Although $\mathrm{CF}_{3} \mathrm{Cl}$ acts as a promotor of combustion up to 0.3 percent addition, for concentrations in excess of 0.1 percent flame speeds at given experimental conditions always decreased as the amount of $\mathrm{CF}_{3} \mathrm{Cl}$ was increased. Likewise, the maximum flame speed for each addition of $\mathrm{CF}_{3} \mathrm{Cl}$ decreased as the amount was increased and the rate of decrease was $0.0313 \mathrm{ft} / \mathrm{s}$ for each 0.1 percent of added $\mathrm{CF}_{3} \mathrm{Cl}$.

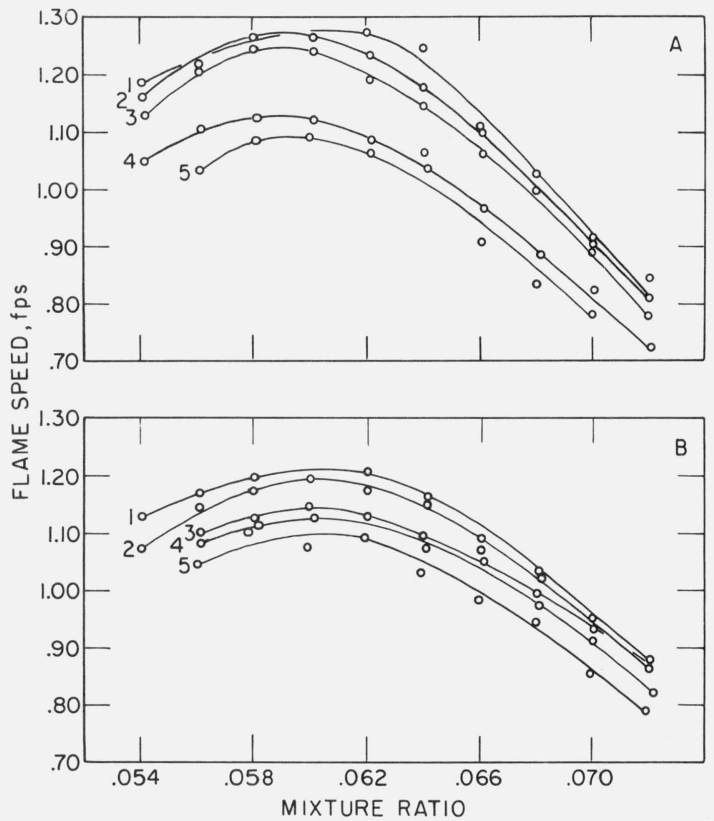

Figure 7. Effect of $\mathrm{CCIF}_{3}$ on the flame speed of methane-air. $\mathrm{CF}, \mathrm{Cl}$ added: $1=0.1 \%: 2=0.2 \%: 3=0.3 \%: 4=0.4 \%$ and $5=0.5 \%$. Gas velocity: $A=4 \mathrm{ft} / \mathrm{s}$ and $B=5 \mathrm{ft} / \mathrm{s}$.

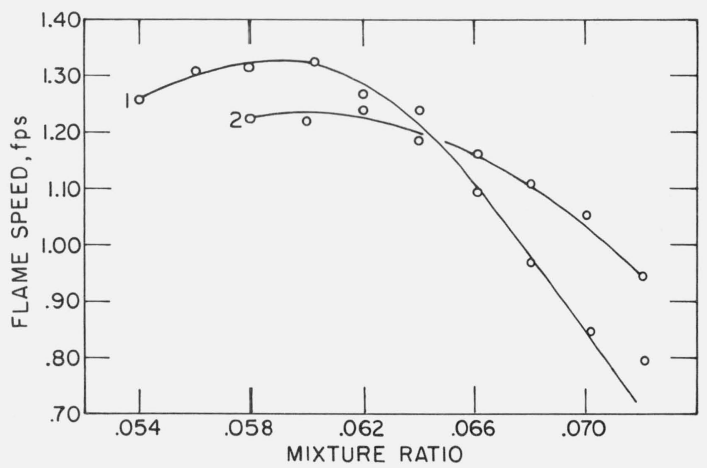

FIGURE 8. Effect of $\mathrm{CCIF}_{3}$ on the flame speed of methane-air. $0.1 \% \mathrm{CCl}_{3}$ added. Gas velocity: $1=3 \mathrm{ft} / \mathrm{s}$ and $2=6 \mathrm{ft} / \mathrm{s}$. 


\subsection{Dichlorofluoromethane, $\mathrm{CHCl}_{2} \mathrm{~F}$}

At the addition of 0.1 and 0.2 percent $\mathrm{CHCl}_{2} \mathrm{~F}$ to the combustion air, maximum flame speeds were larger than those observed for methane-air, while at additions of $0.3,0.4$, and 0.5 percent of $\mathrm{CHCl}_{2} \mathrm{~F}$, maximum flame speeds were less than for methane-air. When 0.1 percent $\mathrm{CHCl}_{2} \mathrm{~F}$ was added, up to mixture ratio 0.066 , flame speed was larger than for methaneair. For mixtures richer in fuel than mixture ratio 0.066 , the flame speeds of mixtures containing 0.1 percent of $\mathrm{CHCl}_{2} \mathrm{~F}$ added to the air were less than the corresponding flame speed of methane-air. When 0.2 percent of $\mathrm{CHCl}_{2} \mathrm{~F}$ was present in the combustion air, flame speeds, up to mixture ratio 0.064 , were larger than the corresponding flame speed of methaneair. In mixtures richer than 0.064, the flame speeds were smaller than the corresponding flame speed of methane-air. At $0.3,0.4$, and 0.5 percent addition of $\mathrm{CHCl}_{2} \mathrm{~F}$, only at mixture ratio of 0.054 was the flame speed larger than that of methane-air.

$\mathrm{CHCl}_{2} \mathrm{~F}$ can act either as a promotor or as an inhibitor of the combustion of methane. Based on its effect on the maximum flame speed, $\mathrm{CHCl}_{2} \mathrm{~F}$ becomes an inhibitor only when 0.3 percent or more is added to the air. However, even at 0.1 percent addition, $\mathrm{CHCl}_{2} \mathrm{~F}$ acts as an inhibitor in fuel-rich mixtures.

Flame speeds became smaller as the amount of $\mathrm{CHCl}_{2} \mathrm{~F}$ was increased. This was true both for the maximum flame speed and for the flame speed at a given mixture ratio. The rate of decrease of maximum flame was $0.0398 \mathrm{ft} / \mathrm{s}$ for each 0.1 percent of added $\mathrm{CHCl}_{2} \mathrm{~F}$. Variation of flame speed with mixture ratio is presented in figures 9 and 10. Maximum flame speeds for given experimental conditions are listed in table 2.

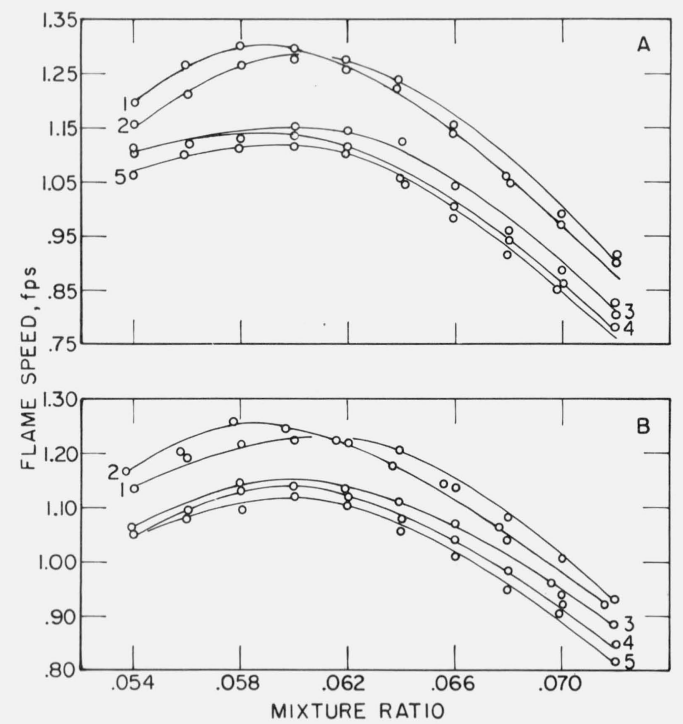

FigURE 9. Effect of $\mathrm{CHCl}_{2} \mathrm{~F}$ on the flame speed of methane-air. CHCl.F added: $l=0.1 \%: 2=0.2 \%: 3=0.3 \%: 4=0.4 \%$ and $5=0.5 \%$. Gas velocity: $A=4 \mathrm{ft} / \mathrm{s}$ and $B=5 \mathrm{ft} / \mathrm{s}$.

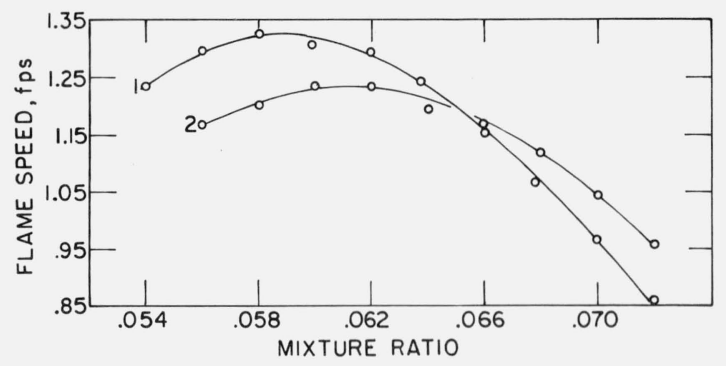

FigURE 10. Effect of $\mathrm{CHCl}_{2} \mathrm{~F}$ on the flame speed of methane-air. $0.1 \% \mathrm{CHCl}_{2} \mathrm{~F}$ added. Gas velocity: $1=3 \mathrm{ft} / \mathrm{s}$ and $2=6 \mathrm{ft} / \mathrm{s}$.

\subsection{Comparison of Bromine and Chlorine Compounds}

None of the chlorinated compounds tested can be considered a good inhibitor of the flame speed of methane-air mixtures. $\mathrm{CH}_{3} \mathrm{Cl}$ is the least effective and $\mathrm{CF}_{3} \mathrm{Cl}$ and $\mathrm{CHCl}_{2} \mathrm{~F}$ are about equal and only slightly better than $\mathrm{CH}_{3} \mathrm{Cl}$. The presence of two chlorine atoms in $\mathrm{CHCl}_{2} \mathrm{~F}$ does not increase its powers of inhibition. Bromine compounds are much more effective in reducing the flame speed of methane-air. For example, at a gas velocity of $4 \mathrm{ft} / \mathrm{s}, 0.5$ percent of $\mathrm{CF}_{3} \mathrm{Br}$ added to the combustion air will reduce the maximum flame speed of methane-air from 1.196 to $0.856 \mathrm{ft} / \mathrm{s}$ which is 72 percent of the uninhibited value. The same percentage of $\mathrm{CF}_{3} \mathrm{Cl}$ will reduce the flame speed to $1.139 \mathrm{ft} / \mathrm{s}$ or 95 percent of the flame speed of methane-air.

A comparison of the bond energies [3] of carbon to chlorine and carbon to bromine $(66.5 \mathrm{kcal} / \mathrm{mol}$ versus $54.0 \mathrm{kcal} / \mathrm{mol}$ ) and of hydrogen to chlorine and hydrogen to bromine $(102.7 \mathrm{kcal} / \mathrm{mol}$ versus $87.3 \mathrm{kcal} / \mathrm{mol})$ shows that chlorine bonds are considerable stronger than bromine bonds. Hence, chlorine compounds will be more stable in flames and less liable to react with the active chain-carrying particles than bromine compounds. This may explain why bromine compounds are more effective as inhibitors than are chlorine compounds.

\subsection{Reaction Zone Thickness}

The position of the schlieren image in a flame marks the region where gradients of density and temperature are steepest and is considered to be the beginning of the reaction zone [7], while the position of the visible image is taken to mark the region where reactions are complete [8]. Hence, the distance between the two images will be a measure of the thickness of the reaction zone. And the thicker the reaction zone, the slower will be the rate of reaction.

In the experimental procedure, the visible and schlieren images of a flame were photographed simultaneously on the same film. Measurements of the distance between images are made on photographic enlargements and the images are rather diffuse. The measurements cannot be considered precise or extremely accurate, but they do establish relative magnitudes and indicate trends. 
Thickness of the reaction zone varies inversely as the flame speed and the minimum thickness, indicating the greatest reaction rate, occurs at or close to the mixture ratio for maximum flame speed. Reaction zone thickness at mixture ratio 0.072 is much larger than at mixture ratio 0.054 . Addition of inhibitors to burning mixtures results in an increased reaction zone thickness and the thickness increases as the amount of inhibitor increases, indicating that the rate of reaction is decreased by the presence of inhibitors. Bromine compounds which are much more effective in reducing flame speeds of methane-air than are chlorine compounds also produce much thicker reaction zones.

Some representative measurements of reaction zone thickness at various experimental conditions are listed in table 4 together with some measurements for methane.

TABLE 4. Reaction zone thicknesses

\begin{tabular}{|c|c|c|c|c|c|}
\hline \multirow{2}{*}{ Inhibitor } & \multirow{2}{*}{$\begin{array}{c}\text { Percent } \\
\text { inhibitor } \\
\text { added to air }\end{array}$} & \multicolumn{4}{|c|}{ Reaction zone thickness, inches } \\
\hline & & $\begin{array}{l}\text { At mixture } \\
\text { ratio } 0.054\end{array}$ & Minimum & $\begin{array}{l}\text { At mixture } \\
\text { ratio } 0.072\end{array}$ & Gas velocity \\
\hline \multirow{3}{*}{$\begin{array}{l}\mathrm{CH}_{4}{ }^{\mathrm{a}}{ }^{-} \mathrm{CH}_{3} \mathrm{Br}\end{array}$} & & & & & $f t / s$ \\
\hline & & 0.0159 & 0.0149 & 0.0196 & 6 \\
\hline & 0.2 & .0203 & .0182 & .0295 & 4 \\
\hline \multirow{2}{*}{$\mathrm{CF}_{3} \mathrm{Br}$} & .5 & .0248 & . .0233 & $\begin{array}{l}.0370 \\
0303\end{array}$ & $\begin{array}{l}3 \\
4\end{array}$ \\
\hline & .5 & & $.0259^{\mathrm{b}}$ & .0405 & 4 \\
\hline \multirow{2}{*}{$\mathrm{CF}_{2} \mathrm{Br}_{2}$} & .1 & .0199 & . 0194 & . 0305 & 4 \\
\hline & .5 & & $.0377^{\mathrm{c}}$ & .0527 & 4 \\
\hline \multirow{2}{*}{$\mathrm{CH}_{3} \mathrm{Cl}$} & .1 & .0195 & .0173 & .0263 & 5 \\
\hline & .5 & .0184 & .0174 & .0303 & 4 \\
\hline \multirow[t]{2}{*}{$\mathrm{CF}_{3} \mathrm{Cl}$} & .1 & .0197 & .0181 & .0280 & 5 \\
\hline & .4 & . 0208 & .0200 & .0297 & 5 \\
\hline \multirow[t]{2}{*}{$\mathrm{CHFCl}_{2}$} & .2 & . 0196 & .0170 & . 0258 & 4 \\
\hline & .5 & . 0185 & . 0178 & . 0298 & 4 \\
\hline
\end{tabular}

${ }^{\text {a }} \mathrm{CH}_{4}$ flame containing no inhibitor.

Leanest stable flame, at 0.060 , blowoff occurred at 0.58

Leanest stable flame, at 0.066 , blowoff occurred at 0.64

\subsection{Effect of Quenching}

All the inhibitors tested were found to be much more effective in reducing flame speeds in rich mixtures than in lean. The maximum flame speed of a mixture containing 0.2 percent of $\mathrm{CF}_{3} \mathrm{Br}$ added to the air is $1.068 \mathrm{ft} / \mathrm{s}$ or 89.3 percent of the maximum flame speed of methane-air, $1.196 \mathrm{ft} / \mathrm{s}$. At mixture ratio 0.054, a lean mixture, the flame speed of the inhibited mixtures is $1.019 \mathrm{ft} / \mathrm{s}$ or 96.4 percent of the corresponding flame speed of methane-air, $1.057 \mathrm{ft} / \mathrm{s}$. At mixture ratio 0.072 , a rich mixture, the flame speed is 0.786 $\mathrm{ft} / \mathrm{s}$ or 80.2 percent of the corresponding flame speed of methane-air, $0.980 \mathrm{ft} / \mathrm{s}$. The flame speed of the inhibited mixture at 0.054 is 95.4 percent of its maximum, while at 0.072 , it is only 73.6 percent of the maximum. The corresponding values for methane-air are 88.3 and 81.9 percent.

Even more striking is the behavior of $\mathrm{CF}_{3} \mathrm{Cl}$. The maximum flame speed at a gas velocity of $4 \mathrm{ft} / \mathrm{s}$ of a mixture of methane and air containing 0.2 percent of $\mathrm{CF}_{3} \mathrm{Cl}$ added to the air is $1.271 \mathrm{ft} / \mathrm{s}$ which is 106.3 percent of the maximum flame speed of methane-air, $1.196 \mathrm{ft} / \mathrm{s}$; an increase in flame speed has resulted.
At mixture ratio 0.054 , the flame speed of the "inhibited" mixture is $1.155 \mathrm{ft} / \mathrm{s}$ which is 109.2 percent of the corresponding flame speed of methane-air, $1.057 \mathrm{ft} / \mathrm{s}$; here, again, an increase in flame speed has resulted. At mixture ratio 0.072 , the flame speed of the inhibited mixture is $0.808 \mathrm{ft} / \mathrm{s}$ which is 82.4 percent of the corresponding flame speed of methane-air, 0.980: a noticeable decrease in flame speed has occurred. At 0.054, the flame speed of the inhibited mixture is 90.0 percent of its maximum, while at 0.072 it is 63.6 percent.

Previously, it had been found that the flame speed of methane-air mixtures, at constant mixture ratio, varies with the velocity of the gas in the nozzle [2]. The flame speed decreases as the gas velocity increases and the change in flame speed is about 2 percent when the gas velocity is doubled. The presence of inhibitors in flames alters this behavior. At a given addition of inhibitor and at constant mixture ratio, the flame speed decreases as the gas velocity increases only when the mixture ratio is 0.064 or less. When the mixture ratio is 0.066 or larger, the flame speed increases sharply as the gas velocity increases and this increase in flame speed may be as much as 20 percent when the gas velocity is increased from 3 to $6 \mathrm{ft} / \mathrm{s}$.

The diameter of the base of the schlieren cone of a methane-air flame increases slightly as the burning mixture becomes richer in fuel [2], and the diameter of the base is larger than the diameter of the port of the nozzle except where conditions producing flashback prevail. Then the diameter of the base is less than the diameter of the port. Again, the addition of an inhibitor changes the behavior of the flame. The diameter of the base of the schlieren cone of an inhibited flame increases as the burning mixture becomes richer in fuel, but only up to mixture ratio 0.064 or 0.066 . When the amount of fuel is increased beyond these values, a sharp decrease in the diameter is found. At the same time, the flame cone becomes extremely elongated. When the maximum amount of inhibitor used in these experiments is present, the diameter of the base of the schlieren cone may be less than the diameter of the port of the nozzle, but flashback does not take place. As the burning mixture becomes richer in fuel, the diameter of the base of the visible flame cone remains practically constant and is larger than the diameters of the schlieren cone and the port of the nozzle. The decrease in the diameter of the base of the schlieren cone and the increase in flame speed with gas velocity, both of which occur in rich mixtures, are related inasmuch as flame speeds are calculated by a total-area method based on the surface area of the schlieren cone and the surface area depends on the diameter of the base.

It is apparent that the position of the schlieren cone in inhibited flames is displaced toward the center relative to the visible cone in fuel-rich mixtures. The increased thickness of the reaction zone is an indication that the rate of reaction has decreased.

Quenching of reactions at the surface of the nozzle also takes place. The phenomena associated with 
flame quenching (quenching distance, dead space, etc.) can be explained qualitatively either by a thermal theory or by a diffusion theory [9]. Probably a diffusion theory is more applicable to the present case. It has been pointed out [4] that small amounts of inhibitors do not lower flame temperatures. Hence, the rapid decrease in flame speeds in inhibited rich mixtures may be explained if active particles (atoms or free radicals) are lost at the surface of the nozzle as well as destroyed by the inhibitor.

\section{Conclusions}

Inhibitors containing bromine are more effective in reducing the flame speed of methane than are inhibitors containing chlorine. $\mathrm{CF}_{2} \mathrm{Br}_{2}$ is more effective as an inhibitor than either $\mathrm{CH}_{3} \mathrm{Br}$ or $\mathrm{CF}_{3} \mathrm{Br}$. Over the range of inhibitor concentrations investigated, it is usually found that maximum flame speeds are reduced proprotionately to the amount of inhibitor added. And all inhibitors tested are more effective in rich mixtures than in lean.

\section{References}

[1] C. Halpern, J. Res. NBS 67A, (Phys. and Chem.) No. 1, 71 (1963).

[2] C. Halpern, J. Res. NBS 60,535 (1958) RP2867.

[3] L. Pauling, Nature of the Chemical Bond, (Cornell Univ. Press, Ithaca, New York, 2d ed., 1940).

[4] W. A. Rosser, H. Wise, and J. Miller, Seventh Symposium (International) on Combustion, p. 175 (Butterworths Scientific Publications, London 1959).

[5] C. F. Cullis, A. Fish, and R. B. Ward, Proc. Roy. Soc. (London) A276, 527 (1963).

[6] W. A. Rosser, S. H. Inami, and H. Wise, Comb. Flame 7, 107 (1963).

[7] J. J. Broeze, Third Symposium (International) on Combustion, p. 146 (Williams and Wilkins, Baltimore, Md., 1949).

[8] A. G. Gaydon and H. G. Wolfhard, Flames, Their Structure, Radiation, and Temperature, p. 96 (Chapman, and Hall, Ltd., London, 1960).

[9] R. Friedman, Third Symposium (International) on Combustion, p. 110 (Williams and Wilkins, Baltimore, Md., 1949).

(Paper 70A2-388) 